\title{
Assessment of Knowledge, Attitudes and Practices of Food Handlers towards Food Safety in Food Preparation Area in Luxor Hotels
}

\section{Suzan Elsayed Abdelrassoul}

High Institute of Tourism and Hotel Management and Monuments Restoration

Abu kir, Alexandria

\section{Hany Atef Kouzmal}

High Institute for Tourism and Hotel Management Luxor City (EGOTH)

\begin{abstract}
Food preparation is one of the most important steps in the food cycle which influences the food quality and increases profitability for the hotel. The food preparation must meet or exceed guests' expectations, because guest satisfaction is the overall goal of food service management. Therefore, food preparation is a complex process, but it can be successful when it focuses on guest needs and expectations. This study aims to measure the awareness and knowledge of food handlers that food preparation procedures in order to improve food acceptance, hygiene and quality in Luxor hotels. In order to achieve this aim, a self-administered questionnaire was distributed to food handler; besides, a personal observation checklist was used to ensure that proper procedures are actually applied. The data were analyzed by SPSS program version 20. The result indicated that food handlers know the right knowledge about food safety but they did not know how to apply it. Food handlers know how to cook safely but they do not apply it practically as the total score of attitude and knowledge $100 \%$ and it is a great score, while the score of food preparation area was $69.2 \%$ and $62.1 \%$ in food preparation practice
\end{abstract}

Keywords: Food preparation area, Food acceptance, Food hygiene, Food quality, Food handlers.

\section{Introduction:}

Food safety is defined by FAO /WHO as the assurance that when food is consumed in the usual manner does not cause harm to human health and wellbeing. ${ }^{1}$

According to the World Health Organization (WHO), up to $30 \%$ of the populations of developed countries are affected by food borne illness each year; more than 75 million people get sick from food related illnesses in the USA resulting in 325,000 hospitalizations and 5,000 deaths annually ${ }^{2}$. In these countries, errors made in food preparation at home, in restaurants, and other public places are important causes of food borne disease $\mathrm{e}^{3}$. The problem is likely to be even more widespread in developing countries where food contamination occurs as a result of poor or inadequate production practices. The WHO further notes that food borne diseases affect people's health and well-being significantly and have economic consequences for the society as a whole. These diseases impose a substantial burden on health-care systems and reduce economic productivity. Moreover, as most of these cases are not reported, the true dimension of the problem is not known. ${ }^{4}$

There is a study that revealed a knowledge gap in food hygiene and handling practice; in addition, there is a statistically significant difference between trained (professional) handlers and non- trained handlers with regard to food hygiene. ${ }^{5}$

The high rate and exorbitant cost of food borne disease further indicate a need for food safety education. Reviews on the topic point to two factors important in developing this food safety education. First, is identifying the unsafe food handling behaviors of different target groups and second addressing those poor behaviors that put an individual at risk for food borne illness Overall, to develop new, more effective, audience-specific food safety education interventions, researchers and health educators need a better understanding of food handling practices and this includes direct observation of consumer practices. ${ }^{6}$ 
Cleaning chemicals can contaminate food if they are not used or stored correctly, so they need to be controlled properly. The transfer of cleaning chemicals to food can occur in a number of ways, for example: chemical residues may be transferred to food containers; chemicals may not be washed away from surfaces following cleaning; if stored incorrectly chemicals could leak into food storage areas. In order to prevent chemical contamination it is important to follow instructions and procedures when using cleaning products. ${ }^{7}$

General requirements Design and construction of food premises: The design and construction of food premises must be appropriate for the activities for which the premises are used; provide adequate space for the activities to be conducted on the food; premises and for the fixtures, fittings and equipment used for those activities; permit the food premises to be effectively cleaned and, if necessary, sanitized; and to the extent that is practicable: exclude dirt, dust, fumes, smoke and other contaminants; not permit the entry of pests; and not provide harborages for pests. Moreover for water supply: Food premises must have an adequate supply of water if water is to be used at the food premises for any of the activities conducted on the food premises. ${ }^{8}$

It is recommended that hand basins should be located at the staff entrances to areas where food is handled. Refer to Storage section 4 and Staff Amenities section. ${ }^{9}$

\section{Aim of the study:}

1. Assessment of food safety knowledge and attitudes of food handlers in food preparation area.

2. Assessment of food safety practices of food handlers in food preparation area and actual application of these procedures.

\section{Methodology:}

\section{Research Population and Sampling Techniques}

\section{Data Collection:}

The target population for this study was food handlers at Luxor hotels. A cross sectional study of food handlers in food preparation area in Luxor city hotels was conducted from October 2014 to January 2015.

A number of 300 questionnaire forms were distributed to juniors and seniors' of food and beverages and kitchen staff in five and four star hotels. 240 completed forms were valid (80\% response rate). Checklists were conducted with the same investigated destinations/resorts for the same purpose. The collected data were analysed using SPSS version 20. A sample of 12 hotels from five and four star hotels in Luxor was chosen to carry out the current research during October 2014 to January 2015 (Table 1).

Table (1): The Research Samples

\begin{tabular}{||l|l|c|c|c||}
\hline No. & \multicolumn{1}{|c|}{ Hotel name } & & Total Rooms & Category \\
\hline 1. & Hiltonluxor Hotel\&Spa & HLH\&S & 236 & 5 Star \\
\hline 2. & Luxor Sheraton Hotel\& Resort & LSH\&R & 290 & 5 Star \\
\hline 3. & $\begin{array}{l}\text { Maritim Jolie Ville Kingsis Land } \\
\text { Resort }\end{array}$ & MJVKIR & 334 & 5 Star \\
\hline 4. & Sofitel Karnak Hotel & SKH & 347 & 5 Star \\
\hline
\end{tabular}




\begin{tabular}{||l|l|c|c|c||}
\hline 5. & Sofitel Winter Palace Hotel & SWPH & 234 & 5 Star \\
\hline 6. & Sonestast. George Hotelluxor & SSGHL & 322 & 5 Star \\
\hline 7. & Steigen Bergernile Palace Hotel & SNPH & 304 & 5 Star \\
\hline 8. & Akhetaton Village & KIEWS & 144 & 4 Star \\
\hline 9. & Almoudira Hotel & AMH & 54 & 4 Star \\
\hline 10. & Elluxor Hotel & ILH & 306 & 4 Star \\
\hline 11. & Iberotel Luxor Hotel & MLH & 185 & 4 Star \\
\hline 12. & Pyramisa Isis Luxor Hotel & PILH & $480+$ time share & 4 Star \\
\hline
\end{tabular}

\section{Results:}

This part of the study included the results of the personnel observation chick list and the questionnaire forms which distributed on Luxor five and four star hotels to assessment of knowledge, attitudes and practices between food handlers regarding food safety in food preparation area in Luxor Hotels.

Statistical package of social sciences (SPSS) version 20.0 for windows was used to analyze and compute the collected data, with the exception of the open - end question. Frequencies counts and percentage distributions were used to assessment of knowledge, attitudes and practices of food handlers regarding food safety in food preparation area in Luxor hotels.

Table (2): Distribution of the studied Handlers according to demographic data $(n=240)$

\begin{tabular}{||c|c|c||}
\hline Factor & No. & $\%$ \\
\hline Age & 12 & 5.0 \\
Less than 20 & 198 & 82.5 \\
From 20 to less than 35 & 12 & 5.0 \\
From 35 to less than 45 & 18 & 7.5 \\
Over 45 years old & & \\
Sex & 240 & 100.0 \\
Male & 0 & 0.0 \\
\hline Female & 57 & 23.8 \\
\hline Job & &
\end{tabular}




\begin{tabular}{|c|c|c|}
\hline First commee & 47 & 19.6 \\
\hline Chief departee & 43 & 17.9 \\
\hline Third commee & 26 & 10.8 \\
\hline Second commee & 22 & 9.2 \\
\hline Other & 21 & 8.8 \\
\hline Helper & 10 & 4.2 \\
\hline Assistant executive chief & 9 & 3.8 \\
\hline Executive chief & 5 & 2.1 \\
\hline \multicolumn{3}{|l|}{ Education } \\
\hline High education & 168 & 70.0 \\
\hline Over mediate & 39 & 16.3 \\
\hline Mediate education & 33 & 13.8 \\
\hline \multicolumn{3}{|l|}{ Nationality } \\
\hline Egyptian & 239 & 99.6 \\
\hline Foreign & 1 & 0.4 \\
\hline
\end{tabular}

The distribution of the studied handlers according to demographic data $(n=240)$ indicated that percentage of studied food handlers was $85.5 \%$ at the age of (20 to 35 years). $100 \%$ of all workers were men in the food preparation area. The greatest percentage was $23.8 \%$ of the jobs assistant chief departee and the lowest percentage was the assistant executive chief 3.8\%. High educated food handlers have the great percentage of $70 \%$ of all food handlers; the lowest percentage was $13.8 \%$ mediate education. All workers in the food preparation area were Egyptian except one person.

According to preparation area table (3) the results showed that $85.8 \%$ of studied samples of food handlers indicated that the floor of the food preparation area usually in good condition. $49.2 \%$ indicate that the floor is usually clean. Waste, solid and liquid contaminants are effectively removed by good drainage and sewage system. $27.5 \%$ of them indicated that sometimes the kitchen and all service food equipment are periodically cleaned and sanitized according to a cleaning schedule. $47.1 \%$ of them indicated that there are usually adequate ventilation and the air conditions is working well. $72.1 \%$ of them indicated that the lighting system usually is in good condition. $54.2 \%$ of them indicated that the lighting usually well covered in the kitchen. 51.3\% of them indicated that there is usually a separate entrance for raw food items and other exit for ready to eat food in the kitchen. $46.7 \%$ of them indicated that there are always separate partitions for vegetables, butchery, sauces, salads, desserts and preserved food. $50.4 \%$ of them indicated that the drainage system usually works well and the same percent indicated in application of effective cleaning schedule for containers, equipment and premises. $57.5 \%$ of them indicated that the kitchen usually has a right location in the hotel according to the standards. $61.7 \%$ of them indicated that food preparation area usually has standard design while $59.2 \%$ of them indicated that sometimes the kitchen located near the receiving and storage area 
while $44.6 \%$ of them indicated that the kitchen floor level is rarely at the same level of receiving and storage area. 53.3\% of them indicated that the area of the kitchen sometimes matches the rank and capacity of hotel, while $46.3 \%$ of them indicated that the temperature of the kitchen sometimes adjusted between 15 and $25^{\circ} \mathrm{C}$. 37.9 of them indicated that sometimes there are not any problems related to maintenance in the kitchen. $37.1 \%$ of them indicated that usually there is fixed firing protection system in the kitchen the highest average mean was $88.25 \%$ with SD 0.63 .

According to food preparation practices table (4) the results showed that $43.3 \%$ of food handlers indicated that sometimes they store leftover food directly in the refrigerator. $37.1 \%$ of them indicated that they are rarely washing hands well and rubbing it at least for 20 seconds after handling of raw food. $44.2 \%$ of them indicated that they are usually clean the kitchen counters well after all preparation activities are completed. $67.5 \%$ of them indicated that sometimes they isolate ready to eat food above raw food in the refrigerator. $60.8 \%$ of them indicated that they are usually using separate knives for meat, vegetables and fruits and the same percent was using separate boards for cutting meat and vegetables. $40.8 \%$ of them indicated that sometimes frozen chicken or meat was thawed in the refrigerator on the lowest shelf. $48.3 \%$ of them indicated that sometimes they wear glove after handling of raw food. 53.3\% of them indicated that sometimes they change the glove after each handling of raw food, the same percentage $60.8 \%$ was eating and smoking in designed area only. $46.7 \%$ of them indicated that they are usually keeping cooked food covered in the kitchen. $35.8 \%$ of them indicated that they are usually clean, sanitize and prepare boards and utensils before using. $29.6 \%$ of them indicated that sometimes they use a thermometer during food preparation. $36.7 \%$ of them usually chick the inner temperature of boiled cooked meat to be over $70^{\circ} \mathrm{c} .36 .3 \%$ of them sometimes use a clean and sanitized thermometer. $46.3 \%$ of them usually serve ready to eat food at a temperature above $60^{\circ} \mathrm{c} .45 .0 \%$ of them usually choose fresh and safe food before food preparation. $72.5 \%$ of them always use clean and safe water in cooking, washing fruits and vegetables, preparing drinks, making ice and cleaning food utensils. $44.6 \%$ of them always wear special uniform during food preparation. $40.8 \%$ of them always separate between raw food and cooked food contact surfaces. 52.9\% of them usually make sure to use clean and dry spoon each time during tasting of food. $53.3 \%$ of them sometimes cover and put a serial number to each served plate the highest average mean was $94.50 \%$ with SD 0.45 .

According to attitudes and knowledge of food handlers table (5) $65.4 \%$ of food handlers always know that the unhygienic practices of food expose the food handler to catch a disease. 50.4\% of them always know that hands must be dried well after washing during food preparation. $99.6 \%$ of them always know that they must cover the head during food preparation. $75.4 \%$ of them always avoid pets in the kitchen. $44.2 \%$ of them sometimes know that the utensils racks must made from metal to be easy cleaned. $35.0 \%$ of them rarely get any educational food practice lessons. 57.5\% always know that they should not wear any rings or jewellery during food preparation. $59.5 \%$ of them always know that they should not eat during food preparation the highest average mean was $99.92 \%$ with SD 0.06 . 
Table (3): Distribution of the studied Handlers according to food preparation area $(\mathrm{n}=240)$

\begin{tabular}{|c|c|c|c|c|c|c|c|c|c|c|c|c|c|}
\hline & \multicolumn{2}{|c|}{ Never } & \multicolumn{2}{|c|}{ Rarely } & \multicolumn{2}{|c|}{$\begin{array}{l}\text { Some } \\
\text { times }\end{array}$} & \multicolumn{2}{|c|}{ Usually } & \multicolumn{2}{|c|}{ Always } & \multirow{2}{*}{ Mean \pm SD } & \multirow{2}{*}{$\mathrm{Av} \%$} & \multirow{2}{*}{ Rank } \\
\hline & No. & $\%$ & No. & $\%$ & No. & $\%$ & No. & $\%$ & No. & $\%$ & & & \\
\hline \multicolumn{14}{|l|}{ Food Preparation Area } \\
\hline 1- The floor of the food preparation area is in good condition & 0 & 0.0 & 0 & 0.0 & 0 & 0.0 & 206 & 85.8 & 34 & 14.2 & $4.14 \pm 0.35$ & 82.83 & 6 \\
\hline $\begin{array}{l}\text { 2- The floor is clean, waste, solid and liquid contaminants are } \\
\text { effectively removed by good drainage and sewage system }\end{array}$ & 0 & 0.0 & 0 & 0.0 & 19 & 7.9 & 103 & 42.9 & 118 & 49.2 & $4.41 \pm 0.63$ & 88.25 & 1 \\
\hline $\begin{array}{l}\text { 3- The kitchen and all service food equipment are periodically } \\
\text { cleaned and sanitized according to a cleaning schedule. }\end{array}$ & 0 & 0.0 & 58 & 24.2 & 66 & 27.5 & 62 & 25.8 & 54 & 22.5 & $3.47 \pm 1.09$ & 69.33 & 14 \\
\hline 4- Adequate ventilation and the air conditions is working well & 0 & 0.0 & 0 & 0.0 & 15 & 6.3 & 113 & 47.1 & 112 & 46.7 & $4.40 \pm 0.61$ & 88.08 & 2 \\
\hline 5- The lighting system is in good condition & 0 & 0.0 & 0 & 0.0 & 0 & 0.0 & 173 & 72.1 & 67 & 27.9 & $4.28 \pm 0.45$ & 85.58 & 5 \\
\hline 6- The lighting is well covered in the kitchen & 0 & 0.0 & 0 & 0.0 & 58 & 24.2 & 130 & 54.2 & 52 & 21.7 & $3.98 \pm 0.68$ & 79.50 & 8 \\
\hline $\begin{array}{l}\text { 7- Is there is a separate entrance for raw food items and other exit for } \\
\text { ready to eat food in the kitchen. }\end{array}$ & 0 & 0.0 & 0 & 0.0 & 62 & 25.8 & 123 & 51.3 & 55 & 22.9 & $3.97 \pm 0.70$ & 79.42 & 9 \\
\hline $\begin{array}{l}\text { 8- Are there separate partitions for vegetables, butchery, sauces, } \\
\text { salads, desserts, preserved food }\end{array}$ & 0 & 0.0 & 15 & 6.3 & 89 & 37.1 & 24 & 10.0 & 112 & 46.7 & $3.97 \pm 1.04$ & 79.42 & 9 \\
\hline 9- Does the drainage system work well & 0 & 0.0 & 0 & 0.0 & 20 & 8.3 & 121 & 50.4 & 99 & 41.3 & $4.33 \pm 0.62$ & 86.58 & 4 \\
\hline
\end{tabular}




\begin{tabular}{|c|c|c|c|c|c|c|c|c|c|c|c|c|c|}
\hline $\begin{array}{l}\text { 11- The kitchen has a right location in the hotel according to the } \\
\text { standards }\end{array}$ & 0 & 0.0 & 0 & 0.0 & 39 & 16.3 & 138 & 57.5 & 63 & 26.3 & $4.10 \pm 65$ & 82.00 & 7 \\
\hline 12- Food preparation area has standard design & 0 & 0.0 & 0 & 0.0 & 52 & 21.7 & 148 & 61.7 & 40 & 16.7 & $3.95 \pm 62$ & 79.00 & 11 \\
\hline $\begin{array}{l}\text { 14- The kitchen floor level is at the same level of receiving and } \\
\text { storage area. }\end{array}$ & 24 & 10.0 & 107 & 44.6 & 74 & 30.8 & 35 & 14.6 & 0 & 0.0 & $2.50 \pm 0.86$ & 50.00 & 18 \\
\hline 15- The area of the kitchen matching the rank and capacity of hotel. & 0 & 0.0 & 38 & 15.8 & 128 & 53.3 & 46 & 19.2 & 28 & 11.7 & $3.27 \pm 0.87$ & 65.33 & 16 \\
\hline $\begin{array}{l}\text { 16- The temperature of the kitchen is adjusted between } 15 \text { and } 25 \\
\text { degree } \mathrm{C} \text {. }\end{array}$ & 0 & 0.0 & 36 & 15.0 & 111 & 46.3 & 69 & 28.8 & 24 & 10.0 & $3.34 \pm 0.85$ & 66.75 & 15 \\
\hline 18- Is there fixed firing protection system in the kitchen. & 0 & 0.0 & 20 & 8.3 & 76 & 31.7 & 89 & 37.1 & 55 & 22.9 & $3.75 \pm 0.90$ & 74.92 & 12 \\
\hline
\end{tabular}


Table (4): Distribution of the studied Handlers according to food preparation practices $(n=240)$

\begin{tabular}{|c|c|c|c|c|c|c|c|c|c|c|c|c|c|}
\hline & \multicolumn{2}{|c|}{ Never } & \multicolumn{2}{|c|}{ Rarely } & \multicolumn{2}{|c|}{$\begin{array}{l}\text { Some } \\
\text { times }\end{array}$} & \multicolumn{2}{|c|}{ Usually } & \multicolumn{2}{|c|}{ Always } & \multirow{2}{*}{$\begin{array}{l}\text { Mean } \\
\pm \text { SD }\end{array}$} & \multirow{2}{*}{ Av $\%$} & \multirow{2}{*}{ Rank } \\
\hline & No. & $\%$ & No. & $\%$ & No. & $\%$ & No. & $\%$ & No. & $\%$ & & & \\
\hline \multicolumn{14}{|l|}{ Food preparation practices } \\
\hline 1- Do you store leftover food directly in the refrigerator & 0 & 0.0 & 0 & 0.0 & 104 & 43.3 & 102 & 42.5 & 34 & 14.2 & $\begin{array}{c}3.71 \pm 0.7 \\
0\end{array} \mid$ & 74.17 & 14 \\
\hline $\begin{array}{l}\text { 2- Washing hands well and rubbing it at least for } 20 \text { seconds after } \\
\text { handling of raw food. }\end{array}$ & 18 & 7.5 & 89 & 37.1 & 79 & 32.9 & 40 & 16.7 & 14 & 5.8 & $\mid \begin{array}{c}2.76 \pm 1.0 \\
1\end{array}$ & 55.25 & 23 \\
\hline $\begin{array}{l}\text { 3- The kitchen counters were cleaned well after all preparation activities } \\
\text { are completed. }\end{array}$ & 0 & 0.0 & 0 & 0.0 & 92 & 38.3 & 106 & 44.2 & 42 & 17.5 & $\begin{array}{c}3.79 \pm 0.7 \\
2\end{array}$ & 75.83 & 12 \\
\hline 4- Isolate ready to eat food above raw food in the refrigerator & 0 & 0.0 & 0 & 0.0 & 162 & 67.5 & 45 & 18.8 & 33 & 13.8 & $\begin{array}{c}3.46 \pm 0.7 \\
3\end{array} \mid$ & 69.25 & 16 \\
\hline 5- Using separate knives for meat, vegetables and fruits. & 0 & 0.0 & 0 & 0.0 & 38 & 15.8 & 146 & 60.8 & 56 & 23.3 & $\begin{array}{c}4.08 \pm 0.6 \\
2\end{array}$ & 81.50 & 6 \\
\hline 6- Do you use separate boards for cutting meat and vegetables & 0 & 0.0 & 0 & 0.0 & 38 & 15.8 & 146 & 60.8 & 56 & 23.3 & $\begin{array}{c}4.08 \pm 0.6 \\
2\end{array}$ & 81.50 & 6 \\
\hline $\begin{array}{l}\text { 7- Frozen chicken or meat was thawed in the refrigeration on the lowest } \\
\text { shelf }\end{array}$ & 0 & 0.0 & 76 & 31.7 & 98 & 40.8 & 51 & 21.3 & 15 & 6.3 & $\begin{array}{c}3.02 \pm 0.8 \\
8\end{array}$ & 60.42 & 22 \\
\hline 8- Do you wear glove after handling of raw food & 0 & 0.0 & 14 & 5.8 & 116 & 48.3 & 84 & 35.0 & 26 & 10.8 & $3.51 \pm 0.7$ & 70.17 & 15 \\
\hline
\end{tabular}




\begin{tabular}{|c|c|c|c|c|c|c|c|c|c|c|c|c|c|}
\hline & & & & & & & & & & & 7 & & \\
\hline 9- Do you change the glove after each handling of raw food & 0 & 0.0 & 34 & 14.2 & 128 & 53.3 & 72 & 30.0 & 6 & 2.5 & $\begin{array}{c}3.21 \pm 0.7 \\
1\end{array}$ & 64.17 & 21 \\
\hline 10- Eating food in designed area only & 0 & 0.0 & 0 & 0.0 & 38 & 15.8 & 146 & 60.8 & 56 & 23.3 & $\begin{array}{c}4.08 \pm 0.6 \\
2\end{array}$ & 81.50 & 6 \\
\hline 11- Smoking in designed area only & 0 & 0.0 & 0 & 0.0 & 38 & 15.8 & 146 & 60.8 & 56 & 23.3 & $\begin{array}{c}4.08 \pm 0.6 \\
2\end{array}$ & 81.50 & 6 \\
\hline 12- Do you keep cooked food covered in the kitchen & 0 & 0.0 & 0 & 0.0 & 53 & 22.1 & 112 & 46.7 & 75 & 31.3 & $\begin{array}{c}4.09 \pm 0.7 \\
3\end{array}$ & 81.83 & 5 \\
\hline 13- Do you clean and sanitize preparing boards and utensils before using & 0 & 0.0 & 27 & 11.3 & 68 & 28.3 & 86 & 35.8 & 59 & 24.6 & $\begin{array}{c}3.74 \pm 0.9 \\
6\end{array} \mid$ & 74.75 & 13 \\
\hline 14- Do you use a thermometer during food preparation & 0 & 0.0 & 67 & 27.9 & 71 & 29.6 & 64 & 26.7 & 38 & 15.8 & $\begin{array}{c}3.30 \pm 1.0 \\
4\end{array}$ & 66.08 & 19 \\
\hline $\begin{array}{l}\text { 15- Do you chick the inner temperature of boiled cooked meat to be over } \\
70 \text { Dc. }\end{array}$ & 0 & 0.0 & 67 & 27.9 & 53 & 22.1 & 88 & 36.7 & 32 & 13.3 & $\begin{array}{c}3.35 \pm 1.0 \\
3\end{array}$ & 67.08 & 17 \\
\hline 16- Do you use a clean and sanitized thermometer. & 0 & 0.0 & 57 & 23.8 & 87 & 36.3 & 70 & 29.2 & 26 & 10.8 & $\begin{array}{c}3.27 \pm 0.9 \\
4\end{array} \mid$ & 65.42 & 20 \\
\hline 17- Do you serve ready to eat food at a temperature above $60 \mathrm{Dc}$ & 0 & 0.0 & 24 & 10.0 & 36 & 15.0 & 111 & 46.3 & 69 & 28.8 & $\begin{array}{c}3.94 \pm 0.9 \\
1\end{array}$ & 78.75 & 10 \\
\hline
\end{tabular}




\begin{tabular}{|c|c|c|c|c|c|c|c|c|c|c|c|c|c|}
\hline 18- Do you choose fresh and safe food before food preparation & 0 & 0.0 & 0 & 0.0 & 54 & 22.5 & 108 & 45.0 & 78 & 32.5 & $\begin{array}{c}4.10 \pm 0.7 \\
4\end{array}$ & 82.00 & 4 \\
\hline $\begin{array}{l}\text { 19- Do you use clean and safe water in cooking, washing fruits and } \\
\text { vegetables, preparing drinks, making ice and cleaning food utensils. }\end{array}$ & 0 & 0.0 & 0 & 0.0 & 0 & 0.0 & 66 & 27.5 & 174 & 72.5 & $\begin{array}{c}4.73 \pm 0.4 \\
5\end{array}$ & 94.50 & 1 \\
\hline 20- Do you wear special uniform during food preparation. & 0 & 0.0 & 0 & 0.0 & 36 & 15.0 & 97 & 40.4 & 107 & 44.6 & $\begin{array}{c}4.30 \pm 0.7 \\
1\end{array}$ & 85.92 & 2 \\
\hline 21- Do you separate between raw food and cooked food contact surfaces & 0 & 0.0 & 0 & 0.0 & 49 & 20.4 & 93 & 38.8 & 98 & 40.8 & $\begin{array}{c}4.20 \pm 0.7 \\
6\end{array}$ & 84.08 & 3 \\
\hline $\begin{array}{l}\text { 22- During tasting of food do you make sure to use clean and dry spoon each } \\
\text { time. }\end{array}$ & 0 & 0.0 & 0 & 0.0 & 74 & 30.8 & 127 & 52.9 & 39 & 16.3 & $\begin{array}{c}3.85 \pm 0.6 \\
7\end{array}$ & 77.08 & 11 \\
\hline 23- Do you cover and put a serial number to each served plate. & 0 & 0.0 & 32 & 13.3 & 128 & 53.3 & 44 & 18.3 & 36 & 15.0 & $\begin{array}{c}3.35 \pm 0.8 \\
9\end{array}$ & 67.00 & 17 \\
\hline
\end{tabular}


Table (5): Distribution of the studied Handlers according to attitudes and knowledge of food handlers $(\mathrm{n}=\mathbf{2 4 0})$

\begin{tabular}{|c|c|c|c|c|c|c|c|c|c|c|c|c|c|}
\hline & \multicolumn{2}{|c|}{ Never } & \multicolumn{2}{|c|}{ Rarely } & \multicolumn{2}{|c|}{$\begin{array}{l}\text { Some } \\
\text { times }\end{array}$} & \multicolumn{2}{|c|}{ Usually } & \multicolumn{2}{|c|}{ Always } & \multirow{2}{*}{ Mean \pm SD } & \multirow{2}{*}{ Av \% } & \multirow{2}{*}{ Rank } \\
\hline & No. & $\%$ & No. & $\%$ & No. & $\%$ & No. & $\%$ & No. & $\%$ & & & \\
\hline \multicolumn{14}{|l|}{ Attitudes and Knowledge of Food Handlers } \\
\hline $\begin{array}{l}\text { 1- Do you know that the un hygienic practices of food expose the food } \\
\text { handler to catch a disease. }\end{array}$ & 0 & 0.0 & 0 & 0.0 & 6 & 2.5 & 77 & 32.1 & 157 & 65.4 & $4.63 \pm 0.53$ & 92.58 & 3 \\
\hline $\begin{array}{l}\text { 2- Do you know that hands must be dried well after washing during food } \\
\text { preparation. }\end{array}$ & 0 & 0.0 & 0 & 0.0 & 0 & 0.0 & 119 & 49.6 & 121 & 50.4 & $4.50 \pm 0.50$ & 90.08 & 5 \\
\hline 3- Do you know that you must cover your head during food preparation & 0 & 0.0 & 0 & 0.0 & 0 & 0.0 & 1 & 0.4 & 239 & 99.6 & $5.0 \pm 0.06$ & 99.92 & 1 \\
\hline 4- Do you know that you have to avoid pets in the kitchen & 0 & 0.0 & 0 & 0.0 & 0 & 0.0 & 59 & 24.6 & 181 & 75.4 & $4.75 \pm 0.43$ & 95.08 & 2 \\
\hline $\begin{array}{l}\text { 5- Do you know that the utensils racks must made from metal to be easy } \\
\text { cleaned }\end{array}$ & 0 & 0.0 & 0 & 0.0 & 106 & 44.2 & 78 & 32.5 & 56 & 23.3 & $3.79 \pm 0.80$ & 75.83 & 7 \\
\hline 6- Do you get any educational food practice lessons. & 0 & 0.0 & 84 & 35.0 & 72 & 30.0 & 58 & 24.2 & 26 & 10.8 & $3.11 \pm 1.01$ & 48.17 & 8 \\
\hline $\begin{array}{l}\text { 7- Do you know that you should not wear any rings or jewelry during food } \\
\text { preparation? }\end{array}$ & 0 & 0.0 & 0 & 0.0 & 18 & 7.5 & 84 & 35.0 & 138 & 57.5 & $4.50 \pm 0.63$ & 90.00 & 5 \\
\hline 8- Do you know that you should not eat during food preparation & 0 & 0.0 & 0 & 0.0 & 0 & 0.0 & 97 & 40.4 & 143 & 59.6 & $4.60 \pm 0.49$ & 91.92 & 4 \\
\hline
\end{tabular}


Table (6) showed that the mean scores of studied food handlers were $70.47 \%$ in food and preparation area, $68.46 \%$ in food preparation practices and $84.0 \%$ in attitudes and knowledge.

Table (6): Descriptive analysis of the studied Handlers according to scores $(n=240)$

\begin{tabular}{|c|c|c|}
\hline & Total score & Mean \%score \\
\hline Food preparation area & & \\
Min. - Max. & $61.0-78.0$ & $59.72-83.33$ \\
Mean \pm SD & $68.74 \pm 4.43$ & $70.47 \pm 6.16$ \\
\hline Food preparation practices & & \\
Min. - Max. & $74.0-97.0$ & $55.43-80.43$ \\
Mean \pm SD & $85.99 \pm 5.51$ & $68.46 \pm 5.99$ \\
Min. - Max. & $31.0-38.0$ & $71.88-93.75$ \\
Mean \pm SD & $34.88 \pm 1.84$ & $84.0 \pm 5.74$ \\
\hline
\end{tabular}

Table (7) showed that $69.2 \%$ of the studied food handlers sample got high score in food preparation area, $62.1 \%$ got high score in food preparation practice, while $100 \%$ of food handlers got high score in attitudes and knowledge which indicate that there is a gap between the attitudes and knowledge and booth food preparation practices and food preparation area this mean knowledge is perfect but practices need improvement.

Table (7): Distribution of level score $(n=240)$

\begin{tabular}{||l|c|c|c|c|c|c||}
\hline \multirow{2}{*}{} & \multicolumn{2}{|c|}{$\begin{array}{c}\text { Low } \\
(<33 \%)\end{array}$} & \multicolumn{2}{c|}{$\begin{array}{c}\text { Moderate } \\
\mathbf{( 3 3 . 3 \%}-\mathbf{6 6 . 6 \% )}\end{array}$} & \multicolumn{2}{c|}{$\begin{array}{c}\text { High } \\
(>66.6 \%)\end{array}$} \\
\cline { 2 - 8 } & No. & $\%$ & No. & $\%$ & No. & $\%$ \\
\hline Food Preparation Area & 0 & 0.0 & 74 & 30.8 & 166 & 69.2 \\
\hline Food preparation practices & 0 & 0.0 & 91 & 37.9 & 149 & 62.1 \\
\hline Attitudes and knowledge & 0 & 0.0 & 0 & 0.0 & 240 & 100.0 \\
\hline
\end{tabular}

Table (8) showed that there is a significant negative correlation between food preparation area and practice, there is a significant positive correlation between food preparation area and attitudes and knowledge of food handlers and there is positive significant correlation between practice and attitude and knowledge of food handlers. 
Table (8): Correlation between knowledge, practice and attitude of Handlers

\begin{tabular}{|l|c|c||}
\hline & $\mathbf{R}$ & $\mathbf{p}$ \\
\hline Food preparation area vs practices & $-0.248^{*}$ & $<0.001^{*}$ \\
\hline Food preparation area vs Attitudes and knowledge & $0.198^{*}$ & $0.002^{*}$ \\
\hline Practices vs Attitudes and knowledge & $0.299^{*}$ & $<0.001^{*}$ \\
\hline
\end{tabular}

r: Pearson coefficient

*: Statistically significant at $\mathrm{p} \leq 0.05$

Regarding food preparation area :Table( 9 ) showed that there is a significant difference between five stars hotels and four stars hotels at: The kitchen and all service food equipment are periodically cleaned and sanitized according to a cleaning schedule as five stars hotels got $100 \%$ while four stars hotels got $40 \%$. There is a significant difference between five and four star hotels in the lighting is well covered in the kitchen and there is a significant difference between five and four star hotels at there is not any problems related to maintenance in the kitchen.

Table (9): Comparison between the two studied groups according to food preparation area

\begin{tabular}{|c|c|c|c|c|c|c|c|c|c|c|}
\hline \multirow{3}{*}{ Food preparation area } & \multicolumn{4}{|c|}{$\begin{array}{c}5 \text { Star hotels } \\
(n=7)\end{array}$} & \multicolumn{4}{|c|}{$\begin{array}{l}4 \text { Star hotels } \\
\quad(n=5)\end{array}$} & \multirow{3}{*}{$\chi^{2}$} & \multirow{3}{*}{${ }^{\mathbf{F E}} \mathbf{p}$} \\
\hline & \multicolumn{2}{|c|}{ Yes } & \multicolumn{2}{|c|}{ No } & \multicolumn{2}{|c|}{ Yes } & \multicolumn{2}{|c|}{ No } & & \\
\hline & No. & $\%$ & No. & $\%$ & No. & $\%$ & No. & $\%$ & & \\
\hline $\begin{array}{l}\text { 1- The floor of the food preparation area } \\
\text { is in good condition }\end{array}$ & 6 & 85.7 & 1 & 14.3 & 1 & 20.0 & 4 & 80.0 & 5.182 & 0.072 \\
\hline $\begin{array}{l}\text { 2- The floor is clean, waste, solid and liquid } \\
\text { contaminants are effectively removed } \\
\text { by good drainage and sewage system }\end{array}$ & 7 & 100.0 & 0 & 0.0 & 3 & 60.0 & 2 & 40.0 & 3.360 & 0.152 \\
\hline $\begin{array}{l}\text { 3- The kitchen and all service food } \\
\text { equipments are periodically cleaned } \\
\text { and sanitized according to a cleaning } \\
\text { schedule. }\end{array}$ & 7 & 100.0 & 0 & 0.0 & 2 & 40.0 & 3 & 60.0 & $5.600^{*}$ & $0.045^{*}$ \\
\hline $\begin{array}{l}\text { 4- Adequate ventilation and the air } \\
\text { conditions is working well }\end{array}$ & 7 & 100.0 & 0 & 0.0 & 5 & 100.0 & 0 & 0.0 & - & - \\
\hline 5- The lighting system is in good condition & 7 & 100.0 & 0 & 0.0 & 5 & 100.0 & 0 & 0.0 & - & - \\
\hline $\begin{array}{c}\text { 6- The lighting is well covered in the } \\
\text { kitchen }\end{array}$ & 7 & 100.0 & 0 & 0.0 & 2 & 40.0 & 3 & 60.0 & $5.600^{*}$ & $0.045^{*}$ \\
\hline
\end{tabular}




\begin{tabular}{|c|c|c|c|c|c|c|c|c|c|c|}
\hline $\begin{array}{l}\text { 7- Is there is a separate entrance for raw } \\
\text { food items and other exit for ready to } \\
\text { eat food in the kitchen. }\end{array}$ & 6 & 85.7 & 1 & 14.3 & 2 & 40.0 & 3 & 60.0 & 2.743 & 0.222 \\
\hline $\begin{array}{l}\text { 8- Are there separate partitions for } \\
\text { vegetables, butchery, sauces, salads, } \\
\text { desserts, preserved food }\end{array}$ & 6 & 85.7 & 1 & 14.3 & 2 & 40.0 & 3 & 60.0 & 2.743 & 0.222 \\
\hline 9- Does the drainage system work well & 7 & 100.0 & 0 & 0.0 & 5 & 100.0 & 0 & 0.0 & - & - \\
\hline $\begin{array}{l}\text { 10- Do you apply effective cleaning } \\
\text { schedule for containers ,equipments } \\
\text { and premises }\end{array}$ & 7 & 100.0 & 0 & 0.0 & 4 & 80.0 & 1 & 20.0 & 1.527 & 0.417 \\
\hline $\begin{array}{l}\text { 11- The kitchen has a right location in the } \\
\text { hotel according to the standards }\end{array}$ & 7 & 100.0 & 0 & 0.0 & 5 & 100.0 & 0 & 0.0 & - & - \\
\hline $\begin{array}{l}\text { 12- Food preparation area has standard } \\
\text { design }\end{array}$ & 7 & 100.0 & 0 & 0.0 & 5 & 100.0 & 0 & 0.0 & - & - \\
\hline $\begin{array}{l}\text { 13- Is the kitchen located near the receiving } \\
\text { and storage area. }\end{array}$ & 7 & 100.0 & 0 & 0.0 & 4 & 80.0 & 1 & 20.0 & 1.527 & 0.417 \\
\hline $\begin{array}{l}\text { 14- The kitchen floor level is at the same } \\
\text { level of receiving and storage area. }\end{array}$ & 7 & 100.0 & 0 & 0.0 & 3 & 60.0 & 2 & 40.0 & 3.360 & 0.152 \\
\hline $\begin{array}{l}\text { 15- The area of the kitchen matching the } \\
\text { rank and capacity of hotel. }\end{array}$ & 7 & 100.0 & 0 & 0.0 & 3 & 60.0 & 2 & 40.0 & 3.360 & 0.152 \\
\hline $\begin{array}{l}\text { 16- The temperature of the kitchen is } \\
\text { adjusted between } 15 \text { and } 25 \text { degree } C \text {. }\end{array}$ & 6 & 85.7 & 1 & 14.3 & 2 & 40.0 & 3 & 60.0 & 2.743 & 0.222 \\
\hline $\begin{array}{l}\text { 17- There is not any problem related to } \\
\text { maintenance in the kitchen. }\end{array}$ & 6 & 85.7 & 1 & 14.3 & 0 & 0.0 & 5 & 100.0 & $8.571^{*}$ & $0.015^{*}$ \\
\hline $\begin{array}{l}\text { 18- Is there fixed firing protection system in } \\
\text { the kitchen? }\end{array}$ & 7 & 100.0 & 0 & 0.0 & 4 & 80.0 & 1 & 20.0 & 1.527 & 0.417 \\
\hline
\end{tabular}

$\chi^{2}$ : value for Chi square

FE: Fisher Exact test

*: Statistically significant at $\mathrm{p} \leq 0.05$

Regarding food preparation practice table(10) showed that there is a significant difference between five stars hotels and four stars hotels regarding isolate ready to eat food above raw food in the refrigerator, Using separate knives for meat, vegetables and fruits and the question Do you use separate boards for cutting meat and vegetables. There is a significant difference between five and four star hotels in: Do you change the glove after each handling of raw food. 
Table (10): Comparison between the two studied groups according to food preparation practices

\begin{tabular}{|c|c|c|c|c|c|c|c|c|c|c|}
\hline \multirow{3}{*}{ Food Preparation Practices } & \multicolumn{4}{|c|}{$\begin{array}{l}5 \text { Star hotels } \\
\quad(n=7)\end{array}$} & \multicolumn{4}{|c|}{$\begin{array}{l}4 \text { Star hotels } \\
\quad(n=5)\end{array}$} & \multirow{3}{*}{$\chi^{2}$} & \multirow{3}{*}{${ }^{\mathrm{FE}} \mathbf{p}$} \\
\hline & \multicolumn{2}{|c|}{ Yes } & \multicolumn{2}{|c|}{ No } & \multicolumn{2}{|c|}{ Yes } & \multicolumn{2}{|c|}{ No } & & \\
\hline & No. & $\%$ & No. & $\%$ & No. & $\%$ & No. & $\%$ & & \\
\hline $\begin{array}{l}\text { 1- Do you store leftover food directly in the } \\
\text { refrigerator. }\end{array}$ & 7 & 100.0 & 0 & 0.0 & 3 & 60.0 & 2 & 40.0 & 3.360 & 0.152 \\
\hline $\begin{array}{l}\text { 2- Washing hands well and rubbing it at } \\
\text { least for } 20 \text { seconds after handling of } \\
\text { raw food. }\end{array}$ & 5 & 71.4 & 2 & 28.6 & 1 & 20.0 & 4 & 80.0 & 3.086 & 0.242 \\
\hline $\begin{array}{l}\text { 3- The kitchen counters were cleaned well } \\
\text { after all preparation activities are } \\
\text { completed. }\end{array}$ & 7 & 100.0 & 0 & 0.0 & 3 & 60.0 & 2 & 40.0 & 3.360 & 0.152 \\
\hline $\begin{array}{l}\text { 4- Isolate ready to eat food above raw food } \\
\text { in the refrigerator. }\end{array}$ & 7 & 100.0 & 0 & 0.0 & 2 & 40.0 & 3 & 60.0 & $5.600^{*}$ & $0.045^{*}$ \\
\hline $\begin{array}{l}\text { 5- Using separate knives for meat, } \\
\text { vegetables and fruits. }\end{array}$ & 7 & 100.0 & 0 & 0.0 & 2 & 40.0 & 3 & 60.0 & $5.600^{*}$ & $0.045^{*}$ \\
\hline $\begin{array}{l}\text { 6- Do you use separate boards for cutting } \\
\text { meat and vegetables }\end{array}$ & 7 & 100.0 & 0 & 0.0 & 2 & 40.0 & 3 & 60.0 & $5.600^{*}$ & $0.045^{*}$ \\
\hline $\begin{array}{c}\text { 7- Frozen chicken or meat was thawed in } \\
\text { the refrigeration on the lowest shelf }\end{array}$ & 7 & 100.0 & 0 & 0.0 & 4 & 80.0 & 1 & 20.0 & 1.527 & 0.417 \\
\hline $\begin{array}{l}\text { 8- Do you wear glove after handling of raw } \\
\text { food }\end{array}$ & 6 & 85.7 & 1 & 14.3 & 2 & 40.0 & 3 & 60.0 & 2.743 & 0.222 \\
\hline $\begin{array}{l}\text { 9- Do you change the glove after each } \\
\text { handling of raw food }\end{array}$ & 5 & 71.4 & 2 & 28.6 & 0 & 0.0 & 5 & 100.0 & $6.122^{*}$ & $0.028^{*}$ \\
\hline 10- Eating food in designed area only & 5 & 71.4 & 2 & 28.6 & 1 & 20.0 & 4 & 80.0 & 3.086 & 0.242 \\
\hline 11- Smoking in designed area only & 6 & 85.7 & 1 & 14.3 & 2 & 40.0 & 3 & 60.0 & 2.743 & 0.222 \\
\hline $\begin{array}{l}\text { 12- Do you keep cooked food covered in } \\
\text { the kitchen }\end{array}$ & 7 & 100.0 & 0 & 0.0 & 5 & 100.0 & 0 & 0.0 & - & - \\
\hline $\begin{array}{l}\text { 13- Do you clean and sanitize preparing } \\
\text { boards and utensils before using }\end{array}$ & 7 & 100.0 & 0 & 0.0 & 5 & 100.0 & 0 & 0.0 & - & - \\
\hline 14- Do you use a thermometer during food & 6 & 85.7 & 1 & 14.3 & 1 & 20.0 & 4 & 80.0 & 5.182 & 0.072 \\
\hline
\end{tabular}




\begin{tabular}{||c|c|c|c|c|c|c|c|c|c|c||}
\hline $\begin{array}{c}\text { preparation } \\
\begin{array}{c}\text { 15- Do you chick the inner temperature of } \\
\text { boiled cooked meat to be over 70 Dc. }\end{array}\end{array}$ & 7 & 100.0 & 0 & 0.0 & 4 & 80.0 & 1 & 20.0 & 1.527 & 0.417 \\
\hline $\begin{array}{c}\text { 16- Do you use a clean and sanitized } \\
\text { thermometer. }\end{array}$ & 4 & 57.1 & 3 & 42.9 & 1 & 20.0 & 4 & 80.0 & 1.656 & 0.293 \\
\hline $\begin{array}{c}\text { 17- Do you serve ready to eat food at a } \\
\text { temperature above 60 Dc }\end{array}$ & 7 & 100.0 & 0 & 0.0 & 5 & 100.0 & 0 & 0.0 & - & - \\
\hline $\begin{array}{l}\text { 18- Do you choose fresh and safe food } \\
\text { before food preparation }\end{array}$ & 7 & 100.0 & 0 & 0.0 & 4 & 80.0 & 1 & 20.0 & 1.527 & 0.417 \\
\hline $\begin{array}{l}\text { 19- Do you use clean and safe water in } \\
\text { cooking, washing fruits and vegetables, } \\
\text { preparing drinks, making ice and } \\
\text { cleaning food utensils. }\end{array}$ & 7 & 100.0 & 0 & 0.0 & 5 & 100.0 & 0 & 0.0 & - & - \\
\hline $\begin{array}{c}\text { 20- Do you wear special uniform during } \\
\text { food preparation. }\end{array}$ & 7 & 100.0 & 0 & 0.0 & 4 & 80.0 & 1 & 20.0 & 1.527 & 0.417 \\
\hline $\begin{array}{c}\text { 21- Do you separate between raw food and } \\
\text { cooked food contact surfaces. }\end{array}$ & 7 & 100.0 & 0 & 0.0 & 5 & 100.0 & 0 & 0.0 & - & - \\
\hline $\begin{array}{l}\text { 22- During tasting of food do you make } \\
\text { sure to use clean and dry spoon each } \\
\text { time. }\end{array}$ & 7 & 100.0 & 0 & 0.0 & 3 & 60.0 & 2 & 40.0 & 3.360 & 0.152 \\
\hline $\begin{array}{l}\text { 23- Do you cover and put a serial number to } \\
\text { each served plate. }\end{array}$ & 5 & 71.4 & 2 & 28.6 & 1 & 20.0 & 4 & 80.0 & 3.086 & 0.242 \\
\hline
\end{tabular}

\section{$\chi^{2}$ : value for Chi square $\quad$ FE: Fisher Exact test}

*: Statistically significant at $\mathrm{p} \leq 0.05$

Regarding table (11) there is a significant difference between five stars hotels and four stars hotels regarding attitude and knowledge of food handlers at the answer of the question of do you get any educational food practice lessons.

Table (11): Comparison between the two studied groups according to attitudes and knowledge of food handlers

\begin{tabular}{|c|c|c|c|c|c|c|c|c|c|c|}
\hline \multirow{3}{*}{$\begin{array}{l}\text { Attitudes and Knowledge of Food } \\
\text { Handlers }\end{array}$} & \multicolumn{4}{|c|}{$\begin{array}{l}5 \text { Star hotels } \\
\quad(n=7)\end{array}$} & \multicolumn{4}{|c|}{$\begin{array}{l}4 \text { Star hotels } \\
\quad(n=5)\end{array}$} & \multirow{3}{*}{$\chi^{2}$} & \multirow{3}{*}{${ }^{\mathrm{FE}} \mathbf{p}$} \\
\hline & \multicolumn{2}{|c|}{ Yes } & \multicolumn{2}{|c|}{ No } & \multicolumn{2}{|c|}{ Yes } & \multicolumn{2}{|c|}{ No } & & \\
\hline & No. & $\%$ & No. & $\%$ & No. & $\%$ & No. & $\%$ & & \\
\hline
\end{tabular}




\begin{tabular}{|c|c|c|c|c|c|c|c|c|c|c|}
\hline $\begin{array}{l}\text { 1- Do you know that the un hygienic } \\
\text { practices of food expose the food } \\
\text { handler to catch a disease. }\end{array}$ & 7 & 100.0 & 0 & 0.0 & 5 & 100.0 & 0 & 0.0 & - & - \\
\hline $\begin{array}{l}\text { 2- Do you know that hands must be dried } \\
\text { well after washing during food } \\
\text { preparation. }\end{array}$ & 7 & 100.0 & 0 & 0.0 & 4 & 80.0 & 1 & 20.0 & 1.527 & 0.417 \\
\hline $\begin{array}{l}\text { 3- Do you know that you must cover your } \\
\text { head during food preparation }\end{array}$ & 7 & 100.0 & 0 & 0.0 & 5 & 100.0 & 0 & 0.0 & - & - \\
\hline $\begin{array}{l}\text { 4- Do you know that you have to avoid pets } \\
\text { in the kitchen }\end{array}$ & 7 & 100.0 & 0 & 0.0 & 4 & 80.0 & 1 & 20.0 & 1.527 & 0.417 \\
\hline $\begin{array}{c}\text { 5- Do you know that the utensils racks must } \\
\text { made from metal to be easy cleaned }\end{array}$ & 6 & 85.7 & 1 & 14.3 & 2 & 40.0 & 3 & 60.0 & 2.743 & 0.222 \\
\hline $\begin{array}{l}\text { 6- Do you get any educational food practice } \\
\text { lessons? }\end{array}$ & 5 & 71.4 & 2 & 28.6 & 0 & 0.0 & 5 & 100.0 & $6.122^{*}$ & $0.028^{*}$ \\
\hline $\begin{array}{l}\text { 7- Do you know that you should not wear } \\
\text { any rings or jewelry during food } \\
\text { preparation? }\end{array}$ & 6 & 85.7 & 1 & 14.3 & 360.0 & 80.0 & 2 & 40.0 & 1.029 & 0.523 \\
\hline $\begin{array}{l}\text { 8- Do you know that you should not eat } \\
\text { during food preparation }\end{array}$ & 6 & 85.7 & 1 & 14.3 & 4 & 80.0 & 1 & 20.0 & 0.069 & 1.000 \\
\hline
\end{tabular}

$\chi^{2}$ : value for Chi square

FE: Fisher Exact test

*: Statistically significant at $\mathrm{p} \leq 0.05$

The results in table (12) compared between five stars hotel and four stars hotels that the total score percent in food preparation area was significant, the total score percent in food preparation practice was significant and the total score percent in attitudes and knowledge of food handlers was significant.

Table (12): Comparison between the two studied groups according to knowledge, practice and attitude

\begin{tabular}{|l|c|c|c|c||}
\hline & $\begin{array}{c}\text { 5 Star hotels } \\
(\mathbf{n}=7)\end{array}$ & $\begin{array}{c}\text { 4 Star hotels } \\
(\mathbf{n}=\mathbf{5})\end{array}$ & $\mathbf{t}$ & $\mathbf{p}$ \\
\hline Food Preparation Area & & & & \\
Total score & $14.0-18.0$ & $7.0-16.0$ & $4.017^{*}$ & $0.002^{*}$ \\
$\quad$ Min.-Max. & & & & \\
\hline
\end{tabular}




\begin{tabular}{|c|c|c|c|c|}
\hline Mean \pm SD & $17.29 \pm 1.50$ & $11.40 \pm 3.51$ & & \\
\hline $\begin{array}{l}\text { Percent score } \\
\qquad \text { Min. - Max. } \\
\text { Mean } \pm \text { SD }\end{array}$ & $\begin{array}{l}77.78-100.0 \\
96.03 \pm 8.31\end{array}$ & $\begin{array}{l}38.89-88.89 \\
63.33 \pm 19.48\end{array}$ & $4.017^{*}$ & $0.002^{*}$ \\
\hline $\begin{array}{l}\text { Food preparation practices } \\
\text { Total score } \\
\text { Min. - Max. } \\
\text { Mean } \pm \text { SD }\end{array}$ & $\begin{array}{l}19.0-23.0 \\
21.0 \pm 1.53\end{array}$ & $\begin{array}{l}10.0-18.0 \\
13.0 \pm 3.74\end{array}$ & 更 & 更 \\
\hline $\begin{array}{l}\text { Percent score } \\
\qquad \text { Min. - Max. } \\
\text { Mean } \pm \text { SD }\end{array}$ & $\begin{array}{l}82.61-100.0 \\
91.30 \pm 6.64\end{array}$ & $\begin{array}{l}43.48-78.26 \\
56.52 \pm 16.27\end{array}$ & $4.519^{*}$ & $0.006^{*}$ \\
\hline $\begin{array}{l}\text { Attitudes and Knowledge of } \\
\text { Food Handlers } \\
\text { Total score } \\
\text { Min. - Max. } \\
\text { Mean } \pm \text { SD }\end{array}$ & $\begin{array}{c}5.0-8.0 \\
7.29 \pm 1.11\end{array}$ & $\begin{array}{c}4.0-7.0 \\
5.40 \pm 1.52\end{array}$ & 更 & 更 \\
\hline $\begin{array}{l}\text { Percent score } \\
\qquad \text { Min. - Max. } \\
\text { Mean } \pm \text { SD }\end{array}$ & $\begin{array}{l}62.50-100.0 \\
91.07 \pm 13.91\end{array}$ & $\begin{array}{c}50.0-87.50 \\
67.50 \pm 18.96\end{array}$ & $2.497^{*}$ & $0.032^{*}$ \\
\hline
\end{tabular}

t: Student t-test

*: Statistically significant at $\mathrm{p} \leq 0.05$

The results in table (13) indicated that there is a significant difference between five and four stars hotels in food preparation practice while there is no significant difference between five and four star hotels in food preparation area and attitude and knowledge of food handlers

Table (13): Comparison between the two studied groups according to level of scores

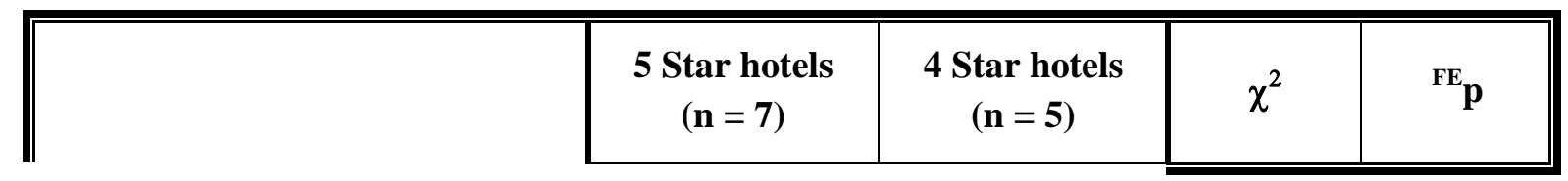




\begin{tabular}{|c|c|c|c|c|c|c|}
\hline & No. & $\%$ & No. & $\%$ & & \\
\hline \multicolumn{7}{|l|}{ Food Preparation Area } \\
\hline Low $(<33 \%)$ & 0 & 0.0 & 0 & 0.0 & & \\
\hline Moderate $(33.3 \%-66.6 \%)$ & 0 & 0.0 & 2 & 40.0 & 3.360 & 0.152 \\
\hline High $(>66.6 \%)$ & 7 & 100.0 & 3 & 60.0 & & \\
\hline \multicolumn{7}{|l|}{ Food preparation practices } \\
\hline Low $(<33 \%)$ & 0 & 0.0 & 0 & 0.0 & & \\
\hline Moderate $(33.3 \%-66.6 \%)$ & 0 & 0.0 & 3 & 60.0 & $5.600^{*}$ & $0.045^{*}$ \\
\hline High $(>66.6 \%)$ & 7 & 100.0 & 2 & 40.0 & & \\
\hline \multicolumn{7}{|l|}{$\begin{array}{l}\text { Attitudes and Knowledge of } \\
\text { Food Handlers }\end{array}$} \\
\hline Low $(<33 \%)$ & 0 & 0.0 & 0 & 0.0 & & \\
\hline Moderate $(33.3 \%-66.6 \%)$ & 1 & 14.3 & 3 & 60.0 & 2.743 & 0.222 \\
\hline High $(>66.6 \%)$ & 6 & 85.7 & 2 & 40.0 & & \\
\hline
\end{tabular}

$\chi^{2}$ : value for Chi square FE: Fisher Exact test $\quad *$ : Statistically significant at $\mathrm{p} \leq 0.05$

The results showed in table (14) the correlation between food preparation area, food preparation practice and attitude and knowledge of food handlers and indicated that there is none significant positive correlation between food preparation area and food preparation practices in five and four hotels, there is none

significant negative correlation between food preparation area and attitude and knowledge in five stars hotels while it was none significant but positive correlation in four stars hotels and there is positive nonsignificant correlation between food preparation practice and attitude and knowledge of food handlers in five stars hotels but it was significant positive correlation in four stars hotels.

Table (14), Correlation between knowledge, practice and attitude in each group

\begin{tabular}{||l|c|c|c|c||}
\hline & \multicolumn{2}{|c|}{$\begin{array}{c}\text { 5 Star hotels } \\
(\mathbf{n}=7)\end{array}$} & \multicolumn{2}{|c|}{$\begin{array}{c}\text { 4 Star hotels } \\
(\mathbf{n}=\mathbf{5})\end{array}$} \\
\cline { 2 - 6 } & $\mathbf{r}$ & $\mathbf{p}$ & $\mathbf{r}$ & $\mathbf{p}$ \\
\hline Food Preparation Area vs Food preparation practices & 0.729 & 0.063 & 0.800 & 0.104 \\
\hline
\end{tabular}




\begin{tabular}{|l|l|l|l|l||}
\hline $\begin{array}{l}\text { Food Preparation Area vs Attitudes and Knowledge of } \\
\text { Food Handlers }\end{array}$ & -0.057 & 0.903 & 0.620 & 0.264 \\
\hline $\begin{array}{l}\text { Food preparation practices vs Attitudes and Knowledge of } \\
\text { Food Handlers }\end{array}$ & 0.490 & 0.264 & $0.925^{*}$ & $0.024^{*}$ \\
\hline
\end{tabular}

r: Pearson coefficient

*: Statistically significant at $\mathrm{p} \leq 0.05$

\section{Discussion:}

From table (2) as the results of demographic data of workers in food preparation area showed that $82.5 \%$ of food handlers were at the age of (20-35) indicated that the work in the kitchen needs high muscular power and great efforts. Ranking in table (2) showed that the highest percent of existing job was $23 \%$ assistant chief departee that indicated that the assistant chief departee is the key person and the actual responsible one in the kitchen, while the executive chief $2.1 \%$ got the lowest percent. The high educated food handlers have got the highest percent $70 \%$ indicated that the work in the kitchen needs highly qualified and well educated workers it followed by over mediate $16.3 \%$ then $13.8 \%$. All of workers were Egyptians except one this is due to foreigners may prefer to work at other places in the kitchen .In contrast to ${ }^{5}$ which indicated that the socio-demographic data of the food handlers is majority $(73.4 \%)$ of the food handlers were females and (26.6\%) were males where most of them(55.6\%) were between21 and 30 years of age with median age of 22 years, majority $(50.2 \%)$ of food handlers completed at least primary school and $(8.1 \%)$ had no formal education.

The ranking of results of studied food handlers in food preparation area table (3) indicated that the high score was in the floor is clean, waste, solid and liquids and contaminants are effectively removed by good drainage sewage system the mean was 4.41. Adequate ventilation and air condition is working well the mean was 4.40 the same as applying of effective cleaning schedule for containers, equipment and premises and then the rest of questions got a serial ranking as: Does drainage the system work well, The lighting system is in good condition, The floor of the food preparation area is in good condition, The kitchen has a right location in the hotel according to the standards, The lighting is well covered in the kitchen, Is there is a separate entrance for raw food items and other exit for ready to eat food in the kitchen, Are there separate partitions for vegetables, butchery, sauces, salads, desserts, preserved food, Food preparation area has standard design, Is there fixed firing protection system in the kitchen, Is the kitchen located near the receiving and storage area. The kitchen and all service food equipment are periodically cleaned and sanitized according to a cleaning schedule; the temperature of the kitchen is adjusted between 15 and $25^{\circ} \mathrm{C}$, The area of the kitchen matching the rank and capacity of hotel. There are not any problems related to maintenance in the kitchen. The kitchen floor level is at the same level of receiving and storage area.

The ranking of results according to food preparation practice table (4) indicated that high mean of scores was in Do you use clean and safe water in cooking, washing fruits and vegetables, preparing drinks, making ice and cleaning food utensils, Do you wear special uniform during food preparation then Do you separate between raw food and cooked food contact surfaces and other questions got serial rank as: Do you choose fresh and safe food before food preparation, Do you keep cooked food covered in the kitchen, Eating food in designed area only, Smoking in designed area only, Using separate knives for meat, vegetables and fruits, Do you use separate boards for cutting meat and vegetables, During tasting of food do you make sure to use clean and dry spoon each time, The kitchen counters were cleaned well after all preparation activities 
are completed, Do you clean and sanitize preparing boards and utensils before using, Do you store leftover food directly in the refrigerator, Do you wear glove after handling of raw food, Isolate ready to eat food above raw food in the refrigerator, Do you chick the inner temperature of boiled cooked meat to be over 70 Dc, Do you cover and put a serial number to each served plate, Do you use a thermometer during food preparation, Do you use a clean and sanitized thermometer, Do you change the glove after each handling of raw food, Frozen chicken or meat was thawed in the refrigeration on the lowest shelf, Washing hands well and rubbing it at least for 20 seconds after handling of raw food.

The ranking of studied food handlers according to attitude and knowledge table (5) the high mean score was, Do you know that you must cover your head during food preparation, Do you know that you have to avoid pets in the kitchen, Do you know that the un hygienic practices of food expose the food handler to catch a disease, Do you know that you should not eat during food preparation, Do you know that hands must be dried well after washing during food preparation, Do you know that you should not wear any rings or jewelry during food preparation, Do you know that hands must be dried well after washing during food preparation, Do you know that the utensils racks must made from metal to be easy cleaned, Do you get any educational food practice lessons.

Table (6) shows that the mean score were $84.0 \%$ in attitude and knowledge, while it was $68.4 \%$ in food preparation practice that means the food handlers knows the right knowledge about food safety but they did not know how to apply it. This agree with study indicated that ${ }^{6}$, there is significant differences were found to exist in the perceptions, opinions, knowledge, and self-reported practices of those who had experienced food-borne illness in the past twelve months versus those who had not. Significant differences were also found with respect to various demographic variables, especially, with respect to age and education levels.

From table (7) The attitude and knowledge was $100 \%$ and it is a great score, while the score of food preparation area was69.2\% and $62.1 \%$ in food preparation practice that the food handlers know how to cook safely but they did not apply it practically and this result verified in table(5 showed that there is a significant negative correlation between food preparation area and practice, there is a significant positive correlation between food preparation area and attitudes and knowledge of food handlers as $\mathrm{P}=0.002$ and there is positive significant correlation between practice and attitude and knowledge of food handlers.

That is agree with study stated that food safety at home may result in increased potential for unsafe food- handling behaviors and consequential increased risk of illness . ${ }^{\mathrm{x}}$

This is agree with a report on consumer food-handling practices indicated that although consumer awareness of pathogens is increasing consumer do not always follow safe handling to minimize pathogens. For example, most consumers do not use a food thermometer to ensure that the food have been cooked to safe internal temperature to kill pathogens. ${ }^{\mathrm{xi}}$

In food preparation area there is a significant difference between five and four hotels in the answers of: the kitchen and all service food equipment are periodically cleaned and sanitized according to a cleaning schedule. Gaps persist, ${ }^{\text {xii }}$ xiii Partnership for Food Safety ${ }^{\text {xiv }}$ although knowledge does not necessarily translate into implementation of correct behaviors. ${ }^{\mathrm{x}}$ There is a review on consumer food-handling found that knowledge, self-reported behaviors, as well as, intentions, did not correspond with observed food handling behaviors. Cleaning and sanitizing according to cleaning schedule the score was $100 \%$ in five stars hotels, while in four stars hotels the score was $40 \%$, this indicates that there is a huge gap between five and four hotels at this point. The same was in the answer of: lighting is well covered in the kitchen. The answer of: there is no any problem related to maintenance is significant. 
From table (11) there is significant difference between five and four hotels in the answer of: do you get any educational food practice lessons. From table (13) there is a significant difference between five and four star hotels in food preparation practice and this result verified in table (10) in the answers of Isolate ready to eat food above raw food in the refrigerator, Using separate knives for meat, vegetables and fruits, do you use separate boards for cutting meat and vegetables, and the answer of do you change the glove after each handling of raw food. This is verified by results in table (14) which indicate that there is significant positive correlation between food preparation practices and attitudes in four stars hotels.

\section{Conclusions}

- The result indicated that $100 \%$ of all workers were men this result agree with the traditions in Upper Egypt and confirm that food preparation work needs great efforts.

- The high educated food handlers have got the highest percent $70 \%$ indicated that the work in the kitchen needs more qualified and well educated workers.

- The food handlers know the right knowledge about food safety but they did not know how to apply it.

- Food handlers know how to cook safely but they did not apply it practically as the total score of attitude and knowledge $100 \%$ and it is a great score, while the score of food preparation area was $69.2 \%$ and $62.1 \%$ in food preparation practice.

- Washing hands well and rubbing it at least for 20 seconds after handling of raw food have got the last position in ranking of food preparation practices.

- There is a huge gap between five and four star hotels as the point of cleaning and sanitizing according to cleaning schedule the score was $100 \%$ in five stars hotels, while in four stars hotels the score was $40 \%$.

- There is a significant difference between five and four star hotels in educational food practice lessons.

\section{Recommendations}

- HACCP-based programs should be implemented in hotels to enhance food safety and quality.

- Application of food safety educational programs

- Training the food handlers about hand washing and glove use.

- Food service establishments must be kept in good sanitary condition.

- Food preparing area must be at the same level with the receiving and storage area.

- The kitchen and all service food equipment should periodically clean and sanitized according to cleaning schedule at four stars hotels.

- Licensing of food handlers and regular inspection targeted to improve their hygienic food practices.

\section{References}

1 WHO, Author. Global Strategy for Food Safety. Geneva: 2002.
WHO
(World
Health
Organization),

(2010).

Available

from," http://www.who.int/mediacentre/factsheets/fs237/en/print.html", [Assessed on 15 December 2014]. 
3 EUfIC (The European Food Information Council), (2010). Available from: "http://www.eufic.org/article/en/food-safety-quality/safe-food-handling/expid/basics-food-safety". [Assessed on 14 December 2014].

4 Byrd-Bredbenner, C; Maurer, J; Wheatley, V; Cottone, E and Clancy M, (2007), Observed Food Safety Behaviours of Young Adults. British Food Journal, 109(7): 519-530.

5 Kibre, M and Abera, B, (2012), The Sanitary Conditions of Food Service Establishments and Food Safety Knowledge and Practices of Food Handlers in Bahir Dar Town. Ethiop J Health Sci, 22(1): $27-$ 35 .

6 Aygen, FG, (2012), Safe Food Handling: Knowledge, Perceptions, and Self-Reported Practices of Turkish Consumers. International Journal of Business and Management, 7(24): 1-11. Available from,"doi:10.5539/ijbm.v7n24p1 URL: http://dx.doi.org/10.5539/ijbm.v7n24p1",[Assessed on 11 December 2014].

7 Allan, P. (2016), Meet Food Safety Requirements when Providing Food and Drink for Individuals, Health and Social Care Diploma, Hodder Education, London, Available from, "https://www.hoddereducation.co.uk/media/Documents/Health\%20and\%20Social\%20Care/9871471806605_HSC _L2_Ch23_online.pdf ", [Assessed on 14 October 2016].

${ }^{8}$ Australia New Zealand Food Standards Code. (2016), Food Premises and Equipment, Available from, "https://www.foodstandards.gov.au/publications/documents/3_2_3.pdf ", [Assessed on 15 March 2016].

9 Mignanelli A, Safa Information for the Safe Design of Commercial Kitchens.

Available from: https://www.safework.sa.gov.au/contentPages/docs/hospSafeDesignComKitchen.pdf, ,[Assessed on 28 January 2015].

x Redmond, E.C and Griffith, C.J. (2003), Consumer Food Handling in The Home: A Review of Food Safety Studies", Journal of Food Protection, Vol. 66, pp. 130-61.

xi US Department of Agriculture and Food Safety Inspection Service (2002), Changes in Consumer Knowledge, Behavior, and Confidence since the 1996 PR/HACCP Final Rule, Available from, "www.fsis.usda.gov/OA/research/haccpimpacts.pdf", [Assessed on 15 November 2014].

xii American Dietetic Association Foundation and Conagra Foundation, (1999), Home Food Safety Benchmark Survey, the American Dietetic Association, Chicago, IL.

xiii Maurer, J; Byrd-Bredbenner, C; Wheatley, V; Clancy, M; and Cottone, E, (2006), Young Adults Report Better Hand Washing Practices Than They Actually Practice", Proceedings of the American Public Health Association 2006 Annual Meeting and Exposition, Boston, MA.

xiv Partnership for Food Safety Education (1998), Fight Bac! Snapshot of Consumer Behavior and Attitudes, Available from, "www.fightbac.org/media/snapshots.htm", [Assessed on 20 October 2014].

xv Patil, S.R; Cates, S and Morales, R., (2005), Consumer Food Safety Knowledge, Practices, and Demographic Differences: Findings from a Meta-Analysis", Journal of Food Protection, Vol. 68, pp. 1884-94. 


\section{تقيم معدى الطعام من حيث المعرفة والاتجاهات والممارسة الفعلية فى فنادق الأقصر}

تهدف هذه الدر اسة إلى قياس وعى معدى الطعام ومعلوماتهم عن إعداد الطعام بالنسبة لأمـاكن إعداد الطعام و عملية إعداد الطعام،

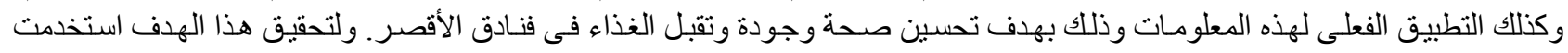

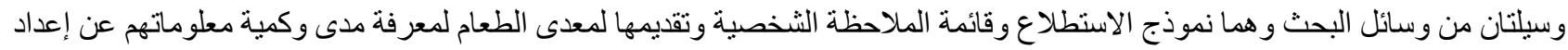

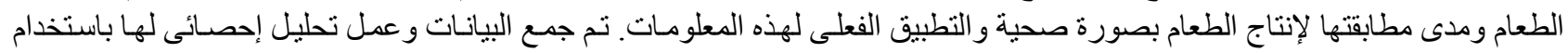

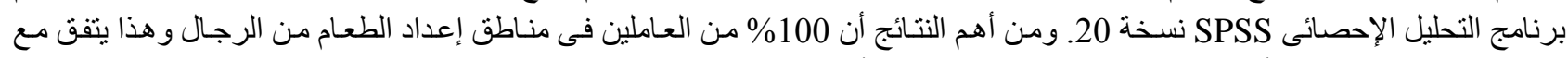

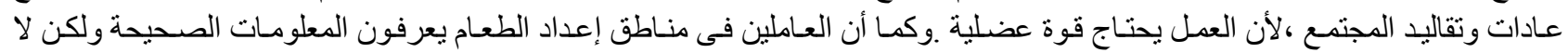
يطبقونها.

الكلمات الدالة: منطقة إعداد الطعام، تقبل الغذاء، سلامة الغذاء، جودة الغذاء، معدو الطعام. 